\title{
Contradiction in determining the nationality of a legal entity: on the criteria of incorporation and siege social
}

\section{Abdurauf ABDUKADIROV ${ }^{1}$}

University of World Economy and Diplomacy, Tashkent, Uzbekistan

\section{ARTICLE INFO}

Article history:

Received September 2020

Received in revised form 15

September 2020

Accepted 25 September

2020

Available online

1 October 2020

\section{Keywords:}

Personal law

Real settlement

Formal settlement

Governing body

Barcelona Traction

ELSI

\begin{abstract}
In this article examined the criteria used to determine the nationality and personal law of a legal entity: the criterion of incorporation and the criterion of settlement. The disadvantages and advantages of incorporation and settlement criteria have been studied through a comparative analysis. In the article also discussed the contradiction between the criteria of incorporation and settlement on the basis of case law, scientific views of scholars and legal acts.

2181-1415/C 2020 in Science LLC.

This is an open access article under the Attribution 4.0 International (CC BY 4.0) license (https://creativecommons.org/licenses/by/4.0/deed.ru)
\end{abstract}

\section{Юридик шахс миллатини аниқлашдаги зиддият: инкорпорация ва утроқлик мезонлари хақида}

\section{Калит сўзлар:}

Шахсий қонун реал ўтроқлик формал ўтроқлик бошқарувчи орган Barcelona Traction ELSI

\section{АННОТАЦИЯ}

Ушбу мақолада юридик шахснинг миллати ва шахсий қонунини аниқловчи мезонлар тадқиқ қилинган: инкорпорация мезони ва ўтроқлик мезони. Инкорпорация ва ўтроқлик мезонларининг камчиликлари ва афзалликлари қиёсий тахлил орқали ўрганилди. Шунингдек, мақолада суд амалиёти, олимларниг илмий қарашлари ва норматив-хуқуқий хужжатлар асосида инкорпорация ва ўтроқлик мезонлари ўртасидаги зиддият мухокама қилинди.

\footnotetext{
${ }^{1}$ University of World Economy and Diplomacy, Tashkent, Uzbekistan email: mustread707@gmail.com
} 
Противоречие

\section{юридического \\ оседлости}

B

лица: о критериях национальности

инкорпорации и

\author{
Ключевые слова: \\ Личный закон \\ реальной оседлости \\ статутарной оседлости \\ управляющий орган \\ Barcelona Traction ELSI
}

\begin{abstract}
АННОТАЦИЯ
В статье рассмотрены критерии, используемые для определения гражданства и личного права юридического лица: критерий регистрации и критерий поселения. Недостатки и преимущества инкорпорации и критериев урегулирования были изучены путем сравнительного анализа. В статье также обсуждается противоречие между критериями регистрации и урегулирования на основе судебной практики, научных взглядов ученых и правовых актов.
\end{abstract}

The fact that companies are actively entering the world economy is a requirement of today. As a result, there is a problem of determining the nationality of legal entity. In practice, this problem is difficult to solve because a legal entity can be established in one state, locate a governing body in another state, make products in a third state, and finally, its founders, shareholders can be citizens or legal entities of different states. However, N.N. Voznesenskaya (2017) consider that "the problem of determining the nationality of legal entities rarely arises as an independent one; usually it is "tied" to another problem that it helps to solve" [17,p.118].

The same can be said about personal law. Therefore, it is expedient to consider the criterions that serve to better understand the concepts of nationality and personal law of a legal entity should be distinguish them from each other in order to understand that they are independent concepts.

Incorporation or management and control. According to this criterion, the state in which the legal entity is established and registered is its personal law, ie the emergence of a legal entity depends on the will of the state. The emergence of this criterion is associated with the activities of companies that in the Middle Ages gradually began to expand their activities through colonial policies. The reason for this, according to Yu.I. Eremina (2015) "it was necessary to establish guarantees for domestic companies that allowed enterprises incorporated in the UK to transfer governing bodies on the territory of the colonies without the risk of losing their legal capacity" [11.p.90].

The criterion of incorporation (lex incorporationis) was originally common in the Anglo-Saxon countries, but today it is used in the United States, Great Britain, Canada, the Netherlands, Switzerland, India, Nigeria, Australia, New Zealand, Cyprus, and many CIS countries (except Georgia). , Is used in the legislation of a number of Latin American countries (Brazil, Venezuela, Mexico, Peru, Cuba).

The criterion of incorporation differs from other criteria in that a legal entity does not lose its legal personality when moving its activities from one state to another. However, the main drawback of this criterion is the most convenient tool for those who want to engage in fraudulent business. Because, according to this criterion, the personal law and nationality of 
the legal entity is determined by the law of the state in which it is established, and, of course, the state with the minimum requirements for fake entrepreneurs is chosen.

In this sense, the application of the criterion of incorporation is not appropriate. As M. Brun (1915) noted many years ago, "If a company's central body is located in the state and has all the costs and main activities, then the state may not agree that such a legal entity is foreign only because its charter is registered abroad" [6,p.10].

Such a situation can be seen in the activities of shell companies which set up to invest. E.Aziano (2012)points to the following model as a shortcoming of the incorporation: A British investor wants to invest in Iran, but there is no such agreement between the two countries. To get out of the situation, a British investor chooses a country that has signed a bilateral investment agreement with Iran, such as Nigeria, and creates a company that acts as an intermediary in that country, through which it invests in Iran [4,p.7].

R. T. Yusifova (2016) explains the situation as follows: "Nowadays, such situations quite often occur, which is why the concepts have become widespread: treaty shopping (purchase of an agreement), corporate nationality planning (planning of residence or nationality), which can be combined with the term "abuse of international agreements". These concepts are used when there is an artificial establishment of companies in order to obtain benefits and benefits from international agreements" [13,p.163]. This does not mean that the criterion of incorporation is inappropriate in the current economic development process, it means that the criterion of incorporation should be applied by other criterion rather than as the dominant criterion in international agreements, and criterion of control should be applied to stop various fraudulent companies from benefiting from international agreements.

For example, in the U.S. state of Delaware, 60\% of the country's 500 largest companies are incorporated in the same state as a result of creating the most favorable environment for entrepreneurs who choose the incorporation [5,p.188]. On the other hand, countries are forced to provide incentives to increase the inflow of foreign investment into their economies, and this sometimes turns into a "struggle" between states.

In public international law, there are cases where the nationality of a legal entity is determined by the criteria of incorporation. The case of Barcelona Traction, Light and Power Company Limited, which was reviewed by a UN court, is one such case in which the dispute arose between Spain and Belgium. Work began in 1958. Initially, the Belgian government will drop its first claim in favor of some stakeholders. However, in 1962, the Spanish government was again taken to the International Court of Justice.

The reason the Belgian government is suing is that although the company is registered in Canada and operates in Spain, Belgian citizens who are among its shareholders will also suffer as a result of the company being declared bankrupt by Spain. However, the court ruled that the company was founded in Canada and that Belgium could not provide diplomatic protection to its citizens, which led to much controversy [12]. Thus, the UN International Court of Justice has concluded that in international public law, the nationality of a legal entity is determined by the criteria of incorporation [14,p.237]. However, in other similar cases, we see that the cour`s mind changed.

Twenty years after the case Barcelona Traction, Light and Power Company Limited, the UN International Court of Justice ruled in favor of Elettronica Sicula SpA (ELSI), United States v. Italy [10] changed the lawsuit on the basis of an agreement signed in 1948 between 
the United States and Italy on Friendship, Trade and Shipping. ELSI was founded in Italy, but its shareholders were Raytheon and Machlett of the United States. The reason for ELSI's manufacturing problems is that the Italian government decided to close its main manufacturing facilities in the Sicilian region and eventually declared the company bankrupt.

Also, the Italian government nationalized the company's assets and did not compensate investors - Raytheon and Machlett. However, ELSI was a subsidiary company of Raytheon and Machlett. As a result, the United States was sued the Italian government for providing diplomatic protection to its shareholders. Although, in this case the company lost that the arguments were not enough court. However, the International Court of Justice decided that there was a genuine connection between the company's shareholders and the state. On the other hand, this means that the court had changed its mind from the incorporation criterion to the control criterion.

Settlement criterion (siege sociale). This criterion applies to Continental Europe, including Austria ( $§ 10$ of the Federal Law on Private International Law of 1978), Germany, Greece (Article 10 of the Civil Code of 1940), Latvia, Lithuania (Article 612 of the Civil Code of 1964), Poland (Article 9 of the Private International Law Act of 1965), Portugal (Article 33 of the Civil Code of 1966), Romania, France and other countries not represented on the European continent, in particular Egypt (Article 11 of the Civil Code of 1948). Georgia) (Article 24 of the Law on Private International Law of 1998), the personal law (nationality) of a legal entity is determined by the legislation of the state where its main governing body is located. The main governing body can be different: the board, the board of directors and other executive bodies. However, he must be able to make decisions and influence the legal entity. This means that the legal entity is economically and politically connected with the state.

There are also two types of settlement criteria in theory: formal and real [17,p.120]. In the formal settlement criteria, the territory of the state in whose charter is specified as the main governing body of the company is its personal law or nationality. In this respect, the formal real settlement criterion leads to shortcomings that lead to the incorporation criterion. In the theory of real settlement, the legal entity is determined by the location of the governing body in practice.

German lawyer X. Shak (2001) also draws attention to the separation of the legal entity based on the charter and the location of the actual governing bodies: "The link of the actual location is a rule of international law for business associations and companies" [15,p.117]. However, E.A. Abrosimova (2015) emphasizes the need to understand real settlement directly when talking about the criterion of settlement, because, in her opinion, the application of the formal criterion of settlement has the same legal consequences as the application of the criterion of incorporation [2,p.36].

According to the Austrian law of 1978, the personal law of a legal entity is the state in which the main governing body is located, and this can be an example of real settlement, and the criterion of formal settlement can be found in Romanian law of 1992. In particular, according to Article 41 of the Law on the Regulation of Private International Legal Relations, the nationality of a legal entity is a state law in which the governing bodies of the legal entity are located on charter [16]. However, the settlement criterion was first written in Article 129 of the Law on Commercial Societies of 18 May 1873 in Belgium, not in Germany, which was a 
staunch supporter of this criterion. Article 129 of the Law on Commercial Societies, adopted on 18 May 1873, stated: "Every company with a principal headquarters in Belgium shall be subject to Belgian law, even if it is established abroad" [3,p.12].

There are two types of settlement criteria in the legislation of the Republic of Turkey: "The legal capacities of legal entities or units of persons or assets are governed by the law of the jurisdiction where their administrative head-offices are located according to their statutes. However, where the de facto central office is located in Turkey, Turkish law may be applied" [1]. According to M.I. Brun (1915), one of the proponents of this criterion, this criterion establishes legal relations and concludes contracts with other participants in civil proceedings, where assignments are given and controlled [6,p.19].

Yu.I. Eremina (2015) rightly returns that the main shortcoming of the settlement criterion is the difficulty or almost impossibility of determining which of the bodies of the legal entity is the main governing body. Furthermore, she believes that the criterion can lead to disputes as a result of having multiple nationalities following the recognition of a legal entity, or can lead to the denial of nationality recognition by any state [11,p.90]. In fact, each state decides the nationality of a legal entity by its own internal laws, which means that any legal entity can have several nationalities as a result of the application of different criteria by the states. On the other hand, it is the domestic law of states.

However, unlike the criterion of incorporation, this criterion does not protect the interests of the founders of the legal entity, but the interests of the state in which it is located [3,p.12], the interests of minority shareholders, workers and creditors, and other third parties [2,p.36]. Using this criteria demands from a legal entity to lose its legal personality which wants to transfer its governing body to another state, in other words, the legal entity must first be liquidated in the first state and again registered in the second state.

In Germany, France, Italy, Austria, and Belgium, which represent, the settlement criterion in the European continent has been widely used before the Centros[7], Überseering[8] and Inspire Art[9] lawsuits, and the settlement criterion has been severely criticized in these cases. Because, according to the European Court, a company established as a member state of the European Union must be able to freely move its administrative center to another member state of the Union, and its legal personality, litigation must be determined by the criterion of incorporation, but settlement doesn'nt give such oppurtunities. So, it contradicts Articles 43 and 48 of the Treaty on European Community.

Each of the criteria considered has certain shortcomings, and none of them is sufficient to define the nationality or personal law of a legal entity as a separate, single criterion. States should therefore adopt laws that allow the application of each criterion in determining the nationality or personal law of a legal entity, and this should be reflected in the international treaties of various international organizations or in bilateral international treaties. Because only the abundance of the criterion allows one to fill in the gaps of the other. For example, the settlement criterion overcomes the main shortcoming of the incorporation criterion, since it does not allow to avoid the imperative rules of the host state.

\section{References}

1. Act on Private International and Procedural Law (1) (Act No. 5718). Retrieved from URL:https://www.ispramed.com/wp-content/uploads/2018/07/IPPL-Turkey.pdf 
2. Abrosimova E.A. (ed), 2015. International private law. Tom. 2: The special part. [Mezhdunarodnoe chastnoe pravo. Tom. 2: Osobennaja chast']. Moscow, (in Russian).

3. Asoskov A.V. (ed), 2003. Pravovye formy uchastija juridicheskih lic v mezhdunarodnom kommercheskom oborote [Legal forms of participation of legal entities in international commercial turnover]. Moscow, (in Russian).

4. Azaino E. U., 2013. Nationality/Treaty Shopping: Can Host Countries Sift the Wheat from the Chaff?. CEPMLP Annual Review (CAR). 16, 7.

5. Basedow J., Kono T. Tübingen., 2006. An Economic Analysis of Private international law.

6. Brun M.I. (ed.), 1915. Legal entities in international private law [Juridicheskie lica v mezhdunarodnom chastnom prave]. Book. 1: 0 lichnom statuse juridicheskogo lica. Peterburg, (in Russian).

7. Case C-212/97. European Court of Justice. Retrieved from URL:https://eurlex.europa.eu/legalcontent/EN/TXT/HTML/?uri=CELEX:61997CJ0212\&from

8. Case C-208/00. European Court of Justice. Retrieved from URL: http://curia.europa.eu/juris/showPdf.jsf?docid=86035\&doclang

9. Case C-167/01. European Court of Justice. Retrieved from URL: http://curia.europa.eu/juris/liste.jsf?language=en\&num=C-167/01

10. Elettronica Sicula SpA (ELSI), United States of America v. Italy. Retrieved from URL:http://www.icjcij.org/docket/index.php?sum=395\&p1=3\&p2=3\&case=76\&p3=5

11. Eremina Ju.I., 2015. Kriterii opredelenija lichnogo zakona i nacional'nosti juridicheskogo lica [Criteria for determining the personal law and nationality of a legal entity]. Juvenis scientia. 1, 90. (in Russian).

12. Barcelona Traction, Light and Power Co. Ltd. (Belgium v. Spain) // 1970 I.C.J., Reports 3. Para. 58.

13. Jusifova R. T., 2016. Nekotorye problemnye aspekty transgranichnoj dejatel'nosti juridicheskih lic [Some problematic aspects of cross-border activities of legal entities]. Aktual'nye problemy rossijskogo prava. 5 (66), 163.

14. Lee L.J., 2006. Barcelona Traction in the 21st century: Revisiting its customary and policy underpinnings 35 years later. Stanford Journal of International Law. 42, 237

15. Shak, H. (ed), 2001. International civil procedural law [Mezhdunarodnoe grazhdanskoe processual'noe pravo]. Moscow, (in Russian)

16. Zakon Rumynskoj Respubliki 1992 g. № 105 primenitel'no k regulirovaniju otnoshenij mezhdunarodnogo chastnogo prava, st.41. Retrieved from URL:https://pravo.hse.ru/intprilaw/doc/041301

17. Voznesenskaja N. N., 2017. Juridicheskie lica v mezhdunarodnom chastnom prave Rossii i Evropejskogo Sojuza [Legal entities in international private law of Russia and the European Union]. Trudy Instituta gosudarstva i prava RAN. 60 (2), 118-120. 